\title{
ADAMTS13, TTP and Beyond
}

\section{Long Zheng*}

Department of Pathology and Laboratory Medicine, The Children's Hospital of Philadelphia and The University of Pennsylvania Perelman School of Medicine, Philadelphia, PA 19194, USA

Keywords: Von willebrand factor cleaving protease; ADAMTS; Thrombotic thrombocytopenic purpura; Inflammation; Thrombosis; Atherosclerosis

\section{Description}

ADAMTS13 (A Disintegrin And Metalloprotease with ThromboSpondin Type 1 repeats, 13), a plasma metalloprotease, cleaves von Willebrand factor (VWF) [1,2]. This cleavage is crucial for reducing the size of VWF multimers and adhesiveness, thereby preventing excessive platelet aggregation and thrombus formation at sites of vascular injury $[3,4]$. Deficiency of plasma ADAMTS13 activity could result in an accumulation of newly released ultra large (UL) VWF on endothelial cells where it is synthesized [5] and in blood [6], leading to a potentially fatal syndrome, thrombotic thrombocytopenic purpura (TTP).

TTP is clinically characterized by profound thrombocytopenia and microangiopathic hemolytic anemia (low hematocrit, elevated serum lactate dehydrogenase, and fragmentation of red blood cells) [7]. Some patients may present signs and symptom of neurologic and/or renal abnormalities [7]. There are two major types of TTP: Hereditary and acquired. Hereditary TTP is caused by inherited mutations of ADAMTS13 gene, which result in severe deficiency $(<5 \%)$ of plasma ADAMTS13 activity [1]. Acquired TTP, on the other hand, is primarily caused by acquired immunoglobulin $\mathrm{G}$ (IgG) autoantibodies against ADAMTS1 $[8,9]$. The autoantibodies bind the exosites that are critical for substrate recognition, thereby inhibiting the cleavage of VWF by ADAMTS13. Recent studies have shown that the spacer domain, particularly those solvent exposed residues comprising exosite 3, appears to be frequently targeted by the IgG autoantibodies in patients with acquired TTP [9-12]. A subtle modification of this exosite creates ADAMTS13 variants that retain proteolytic activity, but exhibit significantly reduced binding and inhibition by a panel of patients' autoantibodies [10].

TTP must be distinguished from other conditions that cause thrombotic microangiopathic findings, which may be ADAMTS13 independent. These conditions include thrombotic microangiopathy occurring after hematopoietic progenitor transplantation [13], disseminated malignancies [14], certain drugs or chemotherapies [15], and infections [16], etc. The data available to date demonstrate that the assay of plasma ADAMTS13 activity and inhibitory autoantibodies may helpful in differential diagnosis, stratification of patients for a more targeted therapy, and prediction of relapses/prognosis [17]. A number of tests have been developed and validated for clinical use. An assay based on fluorescence energy resonance transfer (FRET) and a peptide containing 73 amino acid residues from the central A2 domain of VWF (FRET-VWF73) [18] has gained its popularity due to its simplicity and rapid turn around time. However, an interpretation of this test results should be cautious and a repeated test may be necessary in some cases. In addition, the correlation between the result of FRET assay and that of multimeric assay is relatively poor [19], suggesting the complexity in assessing plasma ADAMTS13 activity in patients.

Plasma infusion or exchange remains the mainstay of treatment for patients with TTP. It reduces mortality rate to less than $20 \%(7 ; 20)$. For hereditary cases, an intermittent infusion of 2 units of fresh frozen plasma (FFP) every 2-3 weeks appears to be sufficient to raise plasma trough levels of ADAMTS13 activity to $0.05-0.1 \mathrm{unit} / \mathrm{ml}$, which prevents the recurrence of acute burst [20]. However, life-long treatment with FFP remains inconvenient and the risk associated with the use of plasma product remains a concern, particularly in pediatric population. Gene therapy with self-inactivated lentiviral vector or an adeno associated viral vector (AAV)-mediated expression of a full-length or a carboxylterminal truncated form of ADAMTS13 (MDTCS) for the correction of hereditary TTP has been evaluated in a murine model of TTP. These results are encouraging [21]. For acquired TTP, plasma exchange (1.5x plasma volume, daily) is often required to replenish the missing ADAMTS13 protease and to remove autoantibodies that inhibit plasma ADAMTS13 activity [22]. Plasma exchange may be discontinued after achieving complete resolution of neurologic symptoms and thrombocytopenia. Approximately $30 \%$ of TTP patients may experience relapse, plasma exchange therapy should be reinstalled as early as possible. In addition, these patients may be benefited from additional adjunctive therapies including corticosteroids, cyclosporine and/or cyclophosphamide, and anti-CD20 monoclonal antibody (rituximab), etc. [20,23]. Novel therapeutics for hereditary or acquired TTP has been evaluated in animal models or clinical trials with some success. These novel modalities include the use of anti-platelet glycoprotein $1 \mathrm{~b}$ (GP1b) monoclonal antibody, nanobody to GP1b, anti-VWF A1 aptamer, and $\mathrm{N}$-acetylcysteine [24]. All these strategies involve in a direct disruption of the interaction between VWF and platelets, which is the pathologic hallmark of TTP and other related arterial thrombotic disorders.

Besides causing TTP, deficiency of plasma ADAMTS13 activity and/ or increase of plasma VWF concentrations have been shown to be the risk factors for myocardial infarction [25], ischemic cerebral infarction [26], preeclampsia [27,28], and cerebral malaria [29]. These epidemiologic findings are consistent with the results obtained from animal studies. For instance, mice with a genetic ablation of Adamts13 gene (Adamts13-/.) exhibit a greater propensity for post ischemic perfusion injury to the heart and the brain than wild type mice or Adamts $13^{-/-}$mice receiving an intravenous infusion of recombinant human ADAMTS13 prior to the injury [30,31]. Moreover, Adamts $13^{-/}$mice develop more and larger atherosclerotic plagues in the aorta and aortic arches than wild type mice after fed normal chew or high fat diet $[32,33]$. Image analyses by intravital microscopy and immunohistochemistry have revealed that leukocytes adhered to the injured vessel walls or monocytes infiltrated into the aortic tissues i.e. macrophages are dramatically increased in Adamts $13^{-/}$mice compared with those in wild type mice $[32,33]$. These

*Corresponding author: Dr. X. Long Zheng, MD, PhD, Associate Professor Department of Pathology and Laboratory Medicine, Children's Hospital of Philadelphia, USA, Tel: 215-590-2565; E-mail: zheng@email.chop.edu

Received August 31, 2012; Accepted August 31, 2012; Published September 03, 2012

Citation: Zheng XL (2012) ADAMTS13, TTP and Beyond. Hereditary Genet 2 : e104. doi:10.4172/2161-1041.1000e104

Copyright: (C) 2012 Zheng XL. This is an open-access article distributed under the terms of the Creative Commons Attribution License, which permits unrestricted use, distribution, and reproduction in any medium, provided the original author and source are credited. 
results indicate that ADAMTS13 plays a role in attenuating acute and chronic inflammation, thereby preventing ischemic/perfusion injury in the heart and brain, as well as the development of atherosclerosis.

In conclusion, the discovery of ADAMTS13 from study of patients with a rare form of hematologic disease, TTP, has provided us with an invaluable tool for further understanding the mechanism of hemostasis and thrombosis and many other related disease processes. Therefore, a success in the development of a novel therapy for TTP may be applicable to the therapeutic intervention of other related diseases due to the abnormality of the ADAMTS13/VWF axis.

\section{Acknowledgement}

This work was supported in part by grants from NIH (P01-HL074124 project 3) and AHA-EIA (0940100N)

\section{Conflict of interest disclosure}

Author has no competing financial interests.

\section{References}

1. Levy GG, Nichols WC, Lian EC, Foroud T, McClintick JN, et al. (2001) Mutations in a member of the ADAMTS gene family cause thrombotic thrombocytopenic purpura. Nature 413: 488-494.

2. Zheng X, Chung D, Takayama TK, Majerus EM, Sadler JE, et al. (2001) Structure of von Willebrand factor-cleaving protease (ADAMTS13), a metalloprotease involved in thrombotic thrombocytopenic purpura. J Biol Chem 276: 41059-41063.

3. Chauhan AK, Motto DG, Lamb CB, Bergmeier W, Dockal M, et al. (2006) Systemic antithrombotic effects of ADAMTS13. J Exp Med 203: 767-776.

4. Xiao J, Jin SY, Xue J, Sorvillo N, Voorberg J, et al. (2011) Essential domains of a disintegrin and metalloprotease with thrombospondin type 1 repeats-13 metalloprotease required for modulation of arterial thrombosis. Arterioscler Thromb Vasc Biol 31: 2261-2269.

5. Dong JF, Moake JL, Nolasco L, Bernardo A, Arceneaux W, et al. (2002) ADAMTS-13 rapidly cleaves newly secreted ultralarge von Willebrand factor multimers on the endothelial surface under flowing conditions. Blood 100: 4033-4039.

6. Moake JL, Rudy CK, Troll JH, Weinstein MJ, Colannino NM, et al. (1982) Unusually large plasma factor VIII:von Willebrand factor multimers in chronic relapsing thrombotic thrombocytopenic purpura. N Engl J Med 307: 1432-1435.

7. Bell WR, Braine HG, Ness PM, Kickler TS (1991) Improved survival in thrombotic thrombocytopenic purpura-hemolytic uremic syndrome. Clinical experience in 108 patients. N Engl J Med 325: 398-403.

8. Tsai HM, Lian EC (1998) Antibodies to von Willebrand factor-cleaving protease in acute thrombotic thrombocytopenic purpura. N Engl J Med 339: 1585-1594.

9. Zheng XL, Wu HM, Shang D, Falls E, Skipwith CG, et al. (2010) Multiple domains of ADAMTS13 are targeted by autoantibodies against ADAMTS13 in patients with acquired idiopathic thrombotic thrombocytopenic purpura. Haematologica 95: 1555-1562.

10. Jian C, Xiao J, Gong L, Skipwith CG, Jin SY, et al. (2012) Gain-of-function ADAMTS13 variants that are resistant to autoantibodies against ADAMTS13 in patients with acquired thrombotic thrombocytopenic purpura. Blood 119: 38363843.

11. Pos W, Crawley JT, Fijnheer R, Voorberg J, Lane DA, et al. (2010) An autoantibody epitope comprising residues $R 660, Y 661$, and $Y 665$ in the ADAMTS13 spacer domain identifies a binding site for the A2 domain of VWF. Blood 115: 1640-1649.

12. Pos W, Sorvillo N, Fijnheer R, Feys HB, Kaijen PH, et al. (2011) Residues Arg568 and Phe592 contribute to an antigenic surface for anti-ADAMTS13 antibodies in the spacer domain. Haematologica 96: 1670-1677.

13. Elliott MA, Nichols WL Jr, Plumhoff EA, Ansell SM, Dispenzieri A, et al. (2003) Posttransplantation thrombotic thrombocytopenic purpura: a single-cente experience and a contemporary review. Mayo Clin Proc 78: 421-430.

14. Mannucci PM, Karimi M, Mosalaei A, Canciani MT, Peyvandi F (2003) Patients with localized and disseminated tumors have reduced but measurable levels of ADAMTS-13 (von Willebrand factor cleaving protease). Haematologica 88 454-458.

15. Pisoni R, Ruggenenti P, Remuzzi G (2001) Drug-induced thrombotic microangiopathy: incidence, prevention and management. Drug Saf 24: 491 501

16. Riggs SA, Wray NP, Waddell CC, Rossen RD, Gyorkey F (1982) Thrombotic thrombocytopenic purpura complicating Legionnaires' disease. Arch Intern Med 142: $2275-2280$

17. Zheng XL (2010) ADAMTS13 testing: why bother? Blood 115: 1475-1476.

18. Kokame K, Nobe Y, Kokubo Y, Okayama A, Miyata T (2005) FRETS-VWF73, a first fluorogenic substrate for ADAMTS13 assay. Br J Haematol 129: 93-100.

19. Hovinga JA, Vesely SK, Terrell DR, Lämmle B, George JN (2010) Survival and relapse in patients with thrombotic thrombocytopenic purpura. Blood 115: 15001511.

20. Furlan M, Lämmle B (2001) Aetiology and pathogenesis of thrombotic thrombocytopenic purpura and haemolytic uraemic syndrome: the role of von Willebrand factor-cleaving protease. Best Pract Res Clin Haematol 14: 437 454

21. Jin SY, Xiao J, Wright FJ, Zheng XL (2010) Correction of ADAMTS13 deficiency by AAV-mediated gene transfer of a C-terminal truncated ADAMTS13 variant in a murine model. Blood 116: 115 (abstr.)

22. Zheng XL, Kaufman RM, Goodnough LT, Sadler JE (2004) Effect of plasma exchange on plasma ADAMTS13 metalloprotease activity, inhibitor level, and clinical outcome in patients with idiopathic and nonidiopathic thrombotic thrombocytopenic purpura. Blood 103: 4043-4049.

23. George JN (2010) How I treat patients with thrombotic thrombocytopenic purpura: 2010. Blood 116: 4060-4069

24. Cines DB, McCrae KR, Zheng XL, Sachais BS, Prak EL, et al. (2012) Antigen and substrate withdrawal in the management of autoimmune thrombotic disorders. Blood. Doi: 10.1182blood-2012-06-389445.

25. Andersson HM, Siegerink B, Luken BM, Crawley JT, Algra A, et al. (2012) High VWF, low ADAMTS13, and oral contraceptives increase the risk of ischemic stroke and myocardial infarction in young women. Blood 119: 1555-1560.

26. Bongers TN, de Maat MP, van Goor ML, Bhagwanbali V, van Vliet $\mathrm{HH}$, et al (2006) High von Willebrand factor levels increase the risk of first ischemic stroke: influence of ADAMTS13, inflammation, and genetic variability. Stroke 37: $2672-2677$

27. Stepanian A, Cohen-Moatti M, Sanglier T, Legendre P, Ameziane N, et al. (2011) Von Willebrand factor and ADAMTS13: a candidate couple for preeclampsia pathophysiology. Arterioscler Thromb Vasc Biol 31: 1703-1709.

28. Moatti-Cohen M, Garrec C, Wolf M, Boisseau P, Galicier L, et al. (2012) Unexpected frequency of Upshaw-Schulman syndrome in pregnancy-onse thrombotic thrombocytopenic purpura. Blood 119: 5888-5897.

29. Kraisin S, Naka I, Patarapotikul J, Nantakomol D, Nuchnoi P, et al. (2011) Association of ADAMTS13 polymorphism with cerebral malaria. Malar $\mathrm{J} 10$ 366. Doi: $10.1186 / 1475-2875-10-366$

30. De Meyer SF, Savchenko AS, Haas MS, Schatzberg D, Carroll MC, et al. (2012) Protective anti-inflammatory effect of ADAMTS13 on myocardial ischemia/ reperfusion injury in mice. Blood. Doi: 10.1182/Blood-2012-06-439935.

31. Zhao BQ, Chauhan AK, Canault M, Patten IS, Yang JJ, et al. (2009) von Willebrand factor-cleaving protease ADAMTS13 reduces ischemic brain injury in experimental stroke. Blood 114: 3329-3334.

32. Gandhi C, Khan MM, Lentz SR, Chauhan AK (2012) ADAMTS13 reduces vascular inflammation and the development of early atherosclerosis in mice. Blood 119: 2385-2391.

33. Jin SY, Tohyama J, Bauer RC, Cao NN, Rader DJ, et al. (2012) Genetic ablation of adamts13 gene dramatically accelerates the formation of early atherosclerosis in a murine model. Arterioscler Thromb Vasc Biol 32: 1817 1823. 